\title{
The English Translation of Goenawan Mohamad's On God and Other Unfinished Things with Special Reference to Poem No. 15: Reiss' Method Application
}

\author{
${ }^{1}$ Almira Ghassani Shabrina Romala, ${ }^{2}$ Harris Hermansyah Setiajid \\ ${ }^{1,2}$ Universitas Sanata Dharma, Yogyakarta \\ 2 (almiraromala@usd.ac.id) \\ ${ }^{2}$ (harris@usd.ac.id)
}

Article History: Submitted 21 November 2018; Accepted 28 November 2018; Published 31 December 2018

\begin{abstract}
This paper aims to explicate and examine one of the poems written by Goenawan Mohamad, Poem No. 15, which is included in his poem and poetic essay collection entitled Tuhan dan Hal-hal yang Tak Pernah Selesai, which was translated into On God and Other Unfinished Things by Laksmi Pamuntjakby applying Reiss' method. This method scrutinizes the translation shift, especially the expression shift and the intralinguistic criteria comprising semantic, lexical, grammatical, and stylistic features.As a creative composition and a piece of literary work that illuminates the imaginative, emotional, and intellectual experience and creativity of its author, a poem is classified in the expressive text type based on Reiss' texttype category.The result shows that there are several intralinguistic criteria and stylistic features maintained and also modified by the translator in the English translation of Goenawan Mohamad's Poem No. 15 in On God and Other Unfinished Things, that is done not only to preserve the aesthetic dimension of the language used in the poem but also to fulfill the expressive function of the text.Byemploying various translation shifts and metaphor translation to make the target text more natural, preserving the relevant aspects of the semantic content, and taking the standpoint of the author in translating the poem, the English translation of Poem No. 15 can fulfill its quality assessment required by its expressive text type.
\end{abstract}

Keywords: expressive text type; Reiss' method; translation shift.

Abstrak.Penelitian ini bertujuan untuk menjelaskan dan menganalisis salah satu puisi yang ditulis oleh Goenawan Mohamad, Puisi No. 15, yang termasuk dalam kumpulan puisinya yang berjudul Tuhan dan Hal-hal yang Tak Pernah Selesai, yang diterjemahkan ke dalam On God and Other Unfinished Things oleh Laksmi Pamuntjak dengan menerapkan metode Reiss. Metode ini meneliti pergeseran terjemahan, terutama pergeseran ekspresi dan kriteria intralinguistik yang terdiri dari fitur semantik, leksikal, gramatikal, dan gaya bahasa. Sebagai komposisi kreatif dan karya sastra yang menggambarkan pengalaman imajinatif, emosional, dan intelektual serta kreativitas penulisnya, sebuah puisi diklasifikasikan dalam jenis teks ekspresif berdasarkan kategori jenis teks Reiss. Hasil penelitian menunjukkan bahwa terdapat beberapa kriteria intralinguistik dan gaya bahasa yang dipertahankan dan juga dimodifikasi oleh penerjemah dalam terjemahan bahasa Inggris dari Goenawan Mohamad's Poem No. 15 di On God dan Other Unfinished Things, yang dilakukan tidak hanya untuk menjaga dimensi estetika dari bahasa yang digunakan dalam puisi tetapi juga untuk memenuhi fungsi ekspresif dari teks. Dengan menggunakan berbagai pergeseran terjemahan dan terjemahan metafora untuk membuat teks target lebih alami, mempertahankan aspek yang relevan dari konten semantik, dan mengambil sudut pandang penulis dalam menerjemahkan puisi, terjemahan bahasa Inggris dari Puisi No. 15 dapat memenuhi penilaian kualitasnya yang diperlukan sebagai jenis teks ekspresifnya.

Kata kunci: jenis teks ekspresif; metode Reiss; pergeseran terjemahan. 


\section{INTRODUCTION}

Goenawan Mohamad is infamous intellectual for his critical and divergent thought on many aspects such as on politics, socio-economic, religion, and also literature. He is notoriously known as a prominent figure in the Indonesian literary world. Most of his works were translated into English, including a poem-poetic essay collectionentitled Tuhan dan Hal-Hal yang Tak Selesai that has been translatedin English by Laksmi Pamuntjak, On God and Other Unfinished Things. There are 99 selected poems compiled in the collection, exploring the breadth of his belief and contemplation to God, religious moments, and also poetic experiences with the expressionsthatat the first sight do not explicitly referred to God. Moreover, the focal point in this paper is Poem No. 15 disclosing a belief and contemplation to God.Therefore, this paper tries to unravel Goenawan Mohamad's Poem No. 15 in On God and Other Unfinished Things to observe the translation shift and test whether Pamuntjak'sEnglish translation is able to fulfill its translation quality required by its expressive text type.

A poem as a creative composition is included as one of the expressive text types. It has a kind of language that says more intensely than ordinary language. As one of the written literary works, it is a form of expressing ideas in a language that illuminates the imaginative, emotional, and intellectual experience of the author in a certain chosen technique to arose specific sense and experience in the readers' mind. Therefore, the role of the translator in translating poem is difficult to imagine as it reflects the idiosyncrasy of an individual author with his distinctive style.In literary translation, the translator transforms words towards images so that the readers will be able to find and occupy their own experiential spaces (Boase-Beier, Fisher, \& Furukawa 2018: 12).Moreover, Landers (2001: 7) states that translating literary works imposes a significant burden on the translator to overcome; hence, he needs a firm grasp on principles and techniques. Besides, maintaining the function of the original text is a challenge for each translator as each text embodies its own distinctive function.

Reiss' method is helpful in translating texts of a different genre because it guides translators how to render a text according to its type.Thus, this paper tries to explicate one of the poems written by Goenawan Mohamad, notoriously known as a prominent figure in Indonesian literary world, Poem No. 15, which is included in his poem collection entitled Tuhan dan Hal-hal yang Tak Pernah Selesai, which was translated into On God and Other Unfinished Things by Laksmi Pamuntjakby applying Reiss' method, which scrutinizes the translation shift, especially the expression shift and also the intralinguistic criteria of the text. These criteria comprising semantic, lexical, grammatical, and stylistic features of the text. It is expected that the result of this examination can shed a light on whether the English translation of Poem No. 15 is able to maintain the sense of the original.

\section{Reiss' Model of Text Types}

Katharina Reiss is a German linguist and translation theorist who is well-known for her text-type category. According to her, texts have an inherent type which differentiates a certain text from other texts. Initially, her works built on the concept of equivalence but viewed the whole textas the level at which communication is achieved and at which equivalence must be sought. Her approach was initially aimed at systematizing the assessment of translation and borrowed from thecategorization of language functions by German psychologist and linguist Karl Bühler (1879-1963). Reiss proposes that each type of text has its own function, be it informative, expressive, operative, or audio-medial. 
(Munday, 2016: 115-116). These distinctive text types will help the translator to specify the appropriate hierarchy of equivalence levels needed for a particular translation and to sharpen his awareness of linguistic markers of communicative function and functional translation units (Nord, 2018: 36-37). Reiss' main characteristics of each text type are summarized as follows.

\section{Informative text type}

As a plain communication of facts, this content-focused text describes information, knowledge, and opinions, such as reports, educational texts, and inventories. The language dimension used to transmit the information is logical or referential and the content or 'topic' is the main focus of the communication (Reiss, 2014: 26-28).

Furthermore, the main function of informative text is to inform the readers about objects and phenomena in the real world that the choice of linguistic and stylistic forms is considered subordinate. In translating informative text type, the translator should attempt to give a correct and complete representation of the source text's content and should be guided, in terms of stylistic choices, by the dominant norms of the target language and culture. As Reiss points out that the informative type is also taken to include "purely phatic communication, where the actual information value is zero and the message is the communication process itself" (Nord, 2018: 36).

\section{Expressive text type}

Reiss argues that this form-focused text type is a creative composition comprising artistic shaping of the content. It includes literary prose (essays, biographies, belles-lettres), imaginative prose (anecdotes, short stories, novellas, romances), and poetry in all its forms, from the didactic to balladry to the purely sentimental (Reiss, 2014: 35).

In this text type, the author uses the aesthetic dimension of language. The author consciously exploits the artistically organized content of expressive and associative possibilities of the language in order to communicate his thoughts in an artistic, creative way (Reiss \& Vermeer, 2014: 182). The stylistic choices made by the author contribute to the meaning of the text, producing an aesthetic effect on the reader. This effect has to be taken into account in translation. If the target text is meant to be an expressive text, the translator should attempt to produce an analogous stylistic effect. In this case, stylistic choices in translation are naturally guided by those made in the source text (Nord, 2018: 36).

Thus, the expressive type is encoded at the level of content and aesthetic organization and requires an analogous form in the translation to create a corresponding impression,so that the translation can become a true equivalent (Reiss, 2014: 32).

\section{Operative text type}

This appeal-focused texts do not simply transfer certain information in a linguistic form; it always presents information with a particular perspective, an explicit purpose, involving a non-linguistic result and functions by inducing behavioral responses in which the aim is to appeal to or persuade the reader or 'receiver' of the text to act in a certain way such as to buy a product (if it is an advertisement), or to agree to an argument (if it is a political 
speech or a barrister's concluding statement). The form of language is dialogic and the focus is appellative (Munday, 2016: 115, Reiss, 2014: 38).

Furthermore, in operative text type, both content and form are considered subordinate to the extralinguistic effect that the text is designed to achieve. Thus, translating this text type should be guided by the overall aim of bringing about the same reaction in the audience, although this might involve changing the content and/or stylistic features of the original as a clear appeal to the hearer or reader of the text is essential in the translation (Nord, 2018: 36, Reiss, 2014: 38).

As itis important that in the target text the same effect is achieved as in the source text, the translator has to depart more from the content and the form of the original than in other types of text and to obtain the fidelity of a similarity in formal principles and the preservation of the aesthetic effect in reproducing every detail in the content of the original text. This aims to accomplish the intended result by the author, preserving the appeal inherent in the text (Reiss, 2014: 41).

\section{Audio-medial texts}

This type of text is commonly called as multimodal text that comprises films and visual and spoken advertisements which supplement written words of the other three functions with visual images and music (Munday, 2016: 117). It is any text that requires the use of and a degree of accommodation to a non-linguistic medium in order to communicate with the hearer, whether in the source or in the target text. Primary examples of this text type include radio and television scripts, such as radio newscasts and reports, topical surveys and dramatic productions (Reiss, 2014: 44).

These texts are distinctive in their dependence on non-linguistic (technical) media and on graphic, acoustic, and visual kinds of expression as they are written to be spoken (or sung) and hence are not read by their audience but heard, often with the aid of some extralinguistic medium. Therefore, the appropriate translation method this type of text must preserve the same effect on the hearer that the original has in the source text (Reiss, 2014: $27,46)$.

Initially, Reiss sought to establish a correlation between text type and translation method, arguing for the need to preserve the predominant function of the text in translation. She suggests a specific translation method according to text type. Thus, what the translator must do in the case of expressive texts, the main concern of the translator should be to try and preserve aesthetic effect alongside relevant aspects of the semantic content (Hatim \& Munday, 2004: 181). Furthermore, the target text should transmit the aesthetic and artistic form of the source text, in addition ensuring the accuracy of information. The translation should use the 'identifying' method, with the translator adopting the standpoint and perspective of the source text author as in literature, the style of the author is a priority. This has to do with its linguistic features and their equivalents in the target language, namely, examining in detail how the translation process has represented the linguistic peculiarities of the source language in the target language (Reiss, 2014: 48).

In expressive texts, the informative aspect is complemented by an aesthetic component showing the author's stylistic choices. This choices made by the author contribute to the meaning of the text, producing an aesthetic effect on the reader. This effect has to be taken into account in translation by attempting to produce an analogous stylistic effect. In this 
case, stylistic choices in translation are naturally guided by those made in the source text (Nord, 2018: 36).

Furthermore, there are some problems that can be identified related to the topic of translating an expressive text. One of the problems is whether the translation is able to fulfill its translation quality required by maintaining the expressive function of the original text and the strategies of the translator in achieving this function in his translation. Therefore, the analysis of the source text and the translated text is needed to reveal the answer to this problem.

\section{METHOD}

This study used the analysis of translated texts which involves the textual comparison of translation with its original (Williams \& Chesterman, 2002: 6). The aspect that becomes the main focus of this paper is the kind of change of shift between source and target texts with the aim to discover patterns of correspondence between the texts.Correspondence in this research is a relation of formal and functional equality between elements of the translation and the source text. The source text is taken from a poetry collection written by Goenawan Mohamad entitled Tuhan dan Hal-Hal yang Tak Selesai consisting of 99 poems in which the researcher focuses on Poem No. 15. This poem collection has been translated in English by Laksmi Pamuntjak, with the title On God and Other Unfinished Things. Both versions were published by KataKita in 2007. To assess the translation quality, the researcher employed source-oriented approach. This approach uses text analysis in order to assess the differences or shifts and to classify various kinds of deviance between the translation and its source text (Williams \& Chesterman, 2002: 8).

As the data source is in the form of poems; thus, it is classified as expressive text type based on Reiss' model of textual category. Furthermore, the researcher used Reiss' method that observed the translation shift, especially the expression shift in the target text. In addition, the intralinguistic instruction criteria that comprise linguistic components such as semantic equivalence, lexical equivalence, and grammatical and stylistic features were also scrutinized in the analysis. The analysis was done per stanza of the poem and then followed by testing whether Laksmi Pamuntjak's English translation of Poem No. 15 is able to fulfill its translation quality required by its expressive text type based on the patterns of correspondence between the texts.

\section{RESULTS AND DISCUSSION}

Goenawan Mohamad's Poem No. 15 in On God and Other Unfinished Things consists of four stanzas. Based on the linguistic forms and stylistic features employed by the author, this poem is originally written in poetic essay form. Therefore, in terms of phonological features, end rhymes are basically not utilized in the original poem, both in the source text and in the target text. The author chooses to emphasize the content and message reflected in the poem more by carefully make a beautiful sequence of words. Consequently, there are examples of internal rhymes and repetitions found in this poem produced by the repeated final vowel sounds of words in the sentences within the stanza. However, several of those musical devices in the source text is not preserved in the target text as the translator decides to maintain the sense and meaning of the poem. 
Furthermore, both in the source text and in the target text, the lexical choice makes the poem reader-friendly as there is no difficult words and technical terms involved without reducing the depth of its substance. The only register and literary word used in the target text is the word thee. However, this word is not also an alien for those who are avid in English literature. Grammatically, the structure of the sentences in the source text is maintained in the target text to ease the readers in contemplating the intended message from the author without feeling any confusion caused by the complex structure of the text. In addition, there is an example of efficiency in the form of intra-system shift employed by the translator observed.

Goenawan Mohamad employs several examples of metaphor and also personification (which also can be classified as metaphor, i.e. humanizing metaphor) in Poem No. 15 which are also translated in metaphors by the translator. This strategy can be used as the concept of the metaphor in the source text does not clash with the target text culture. Moreover, it also ensures the fidelity of the metaphors and eases the readers to understand the ideas being explained in the poem.

In brief, there are several aspects both maintained and also modified by the translator in delivering the message of Goenawan Mohamad's Poem No. 15 in in On God and Other Unfinished Things, not only to preserve the aesthetic dimension of the language used in the poem but also to fulfill the expressive function of the text. The explanation of the textual comparison analysis of the source text and the target text original was done per stanza of the poem. The analysis in the first stanza of the poem is as follows.

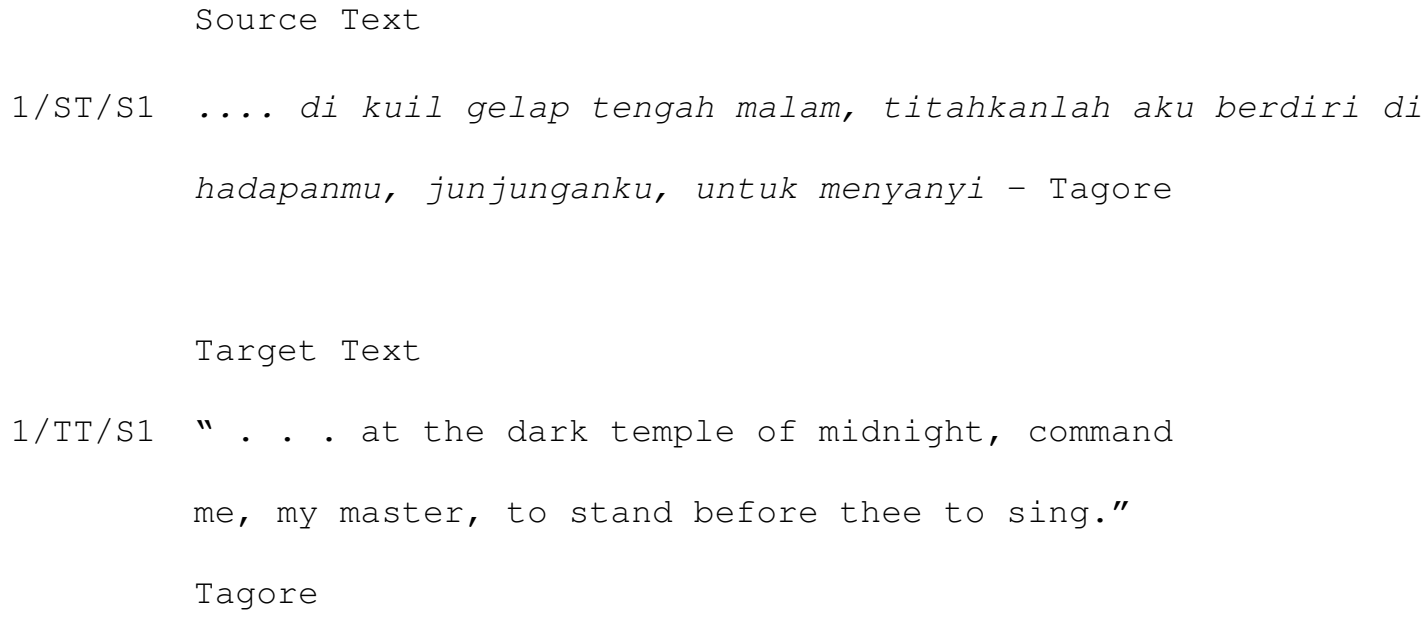

In the first stanza of Poem No. 15, the differences in the graphological level of the source text and target text are clearly shown. The first stanza of the target text is written in double quotation marks which are not used in the source text. Furthermore, the other difference is the indentation of the word Tagore. It is written with a dash in the source text, while it is written in the next line without a dash in the target text.

In addition, the structure of the expression di kuil gelap tengah malam in the source text is maintained in its English translation, at the dark temple of midnight. Both are prepositional phrases that consist of a preposition and a noun phrase. This suggests that the translator preserves the relevant aspects of the semantic content of these phrases. 
The translator employs structure shift or changing of word sequence in the sentence by rearranging the order of the expression titahkanlah aku berdiri di hadapanmu, junjunganku, untuk menyanyi in the source text becomes command me, my master, to stand before thee to sing to emphasize the direct action to stand before thee to sing and also to make the target text more natural in English sense. By choosing this expression, the translator does not preserve the original form of the word order hadapanmu, junjunganku that produces repeated final vowel $[\mathrm{u}]$ in the target text with the corresponding repeated sounds. However, in the target text, a consonance by repeated consonant sounds [m] in the words temple, midnight, command me, and my master is employed as the musical device. Thus, although the repeated final vowel $[\mathrm{u}]$ is not maintained, the musical device in the translated poem is substituted by the use of consonance of consonant sounds $[\mathrm{m}]$.

Moreover, the translator also employs the use of literary word thee in order to give the sense of nobility to the master who is referred to in this poem. Furthermore, in stanza 2 of Poem No. 15, class shift is exploited by the translator which is elaborated in the following datum.

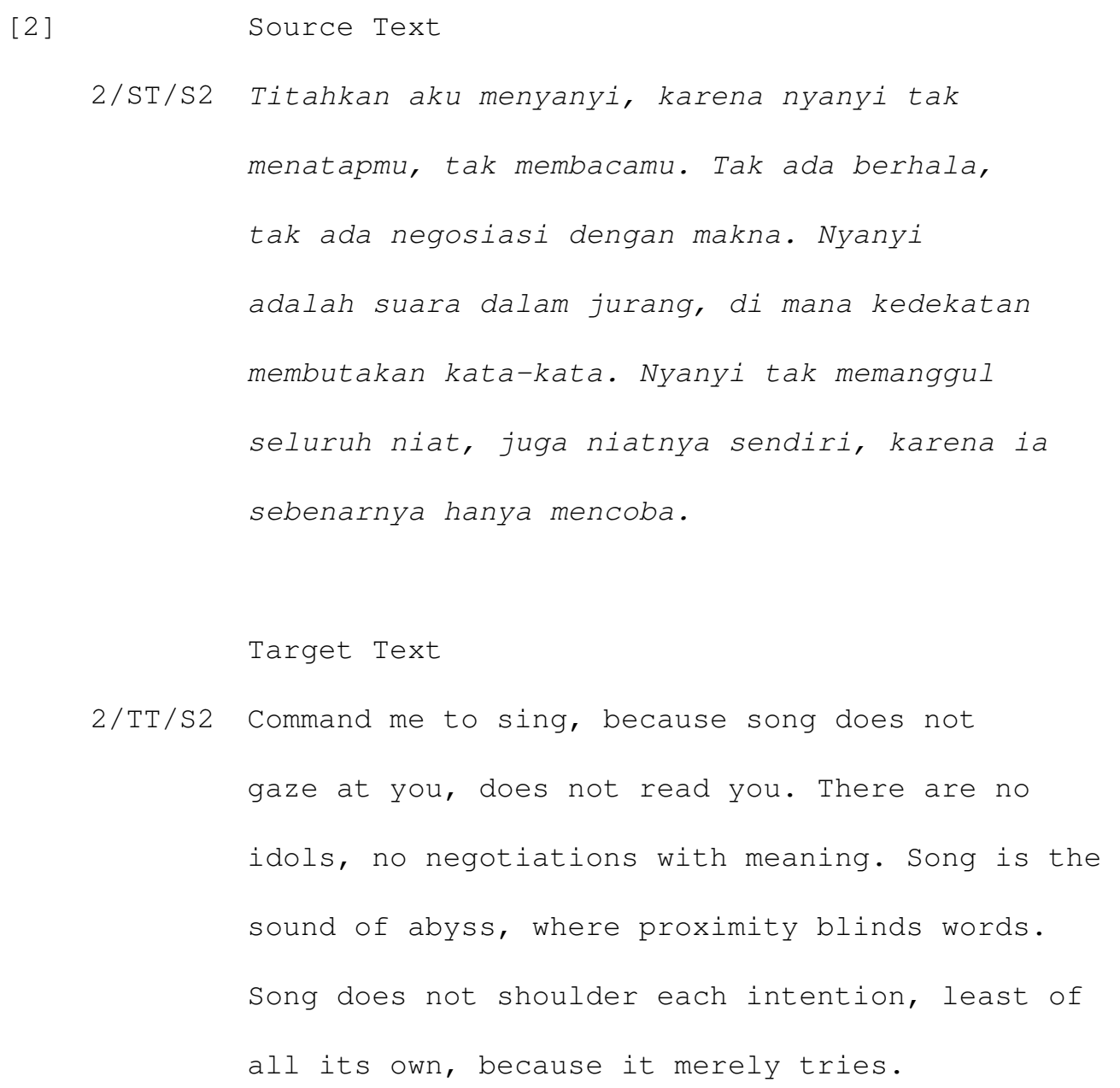

In datum 2, the word nyanyi in the source text is a verb. Meanwhile, in the target text, nyanyi is translated as song which is a noun. Thus, this indicates a class shift is applied by the translator. Furthermore, in maintaining the expressive function of the source text, the metaphors in this stanza are translated as metaphors. The metaphors karena nyanyi tak menatapmu, tak membacamu, di mana kedekatan membutakan kata-kata, and also Nyanyi 
tak memanggul seluruh niat, juga niatnya sendiri, karena ia sebenarnya hanya mencoba are translated by reproducing the same image in the target language by employing because song does not gaze at you, does not read you, where proximity blinds words. Song does not shoulder each intention, least of all its own, because it merely tries. It is in line with the strategies of translating metaphors proposed by Newmark (1988: 107) that the reproduction of the image in the source text suggests it does not clash with the target text culture. Moreover, it also ensures the accuracy of the information that the metaphors will be understood by the readers. In addition, the reproduction of the metaphor also functions to maintain the aesthetic dimension of language in the source text.

Moreover,in this stanza, the translator both maintains and alters the repeated final vowel [u] of the words tak menatapmu, tak membacamu becomes does not gaze at you, does not read you which also employs the repeated final vowel $[\mathrm{u}]$ in the word you. In addition, the the repeated final vowel [a] in Tak ada berhala, tak ada negosiasi dengan makna is translated to There are no idols, no negotiations with meaning which does not have internal rhyme or repeated final sounds. In the target text, several pairs of half-rhyme are observed in There are noidols, no negotiations.Song is the sound of abyss, where proximity blinds words. Song does not shoulder each intention, least of all its own. It is classified as half-rhyme as the pairs do not have identical or exact rhyming sounds, they are only similar in the final consonant sounds. They are idols, negotiations, and words with final consonant sounds [z], and also intention and own with final consonant sounds [n].

Furthermore, seluruh niat which is translated into each intention also signifies there is a shift as seluruh means all. The translator style is illustrated in the use of expression least of all its own as the translation of juga niatnya sendiri. This also shows the employment of style shift of changing the denotation to idiomatic expression.

Moreover, the translator does the omission by not translating the word sebenarnya 'actually' in karena ia sebenarnya hanya mencoba so that it becomes because it merely tries. This suggests an efficiency in translating the sense component in the source text.

There are many highly expressive components in this datum, but the word merely in the last sentence of the target text has a totally expressive function. The translator chooses to overshadow the value, so it would not alter the information content of the message and keep the forcefulness considerably (Baker, 2018: 13). Besides the efficiency in this stanza, it is also shown in datum 3 as follows.

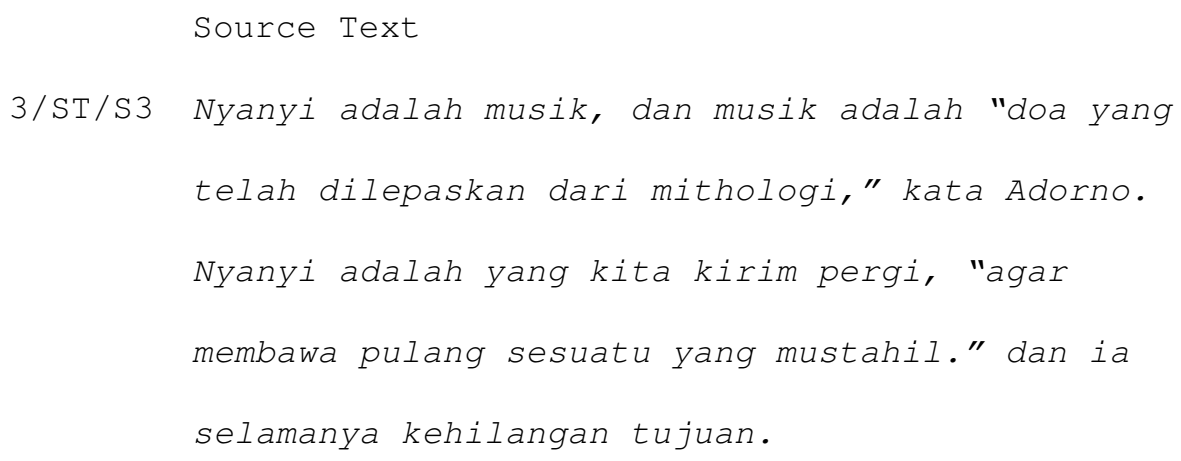




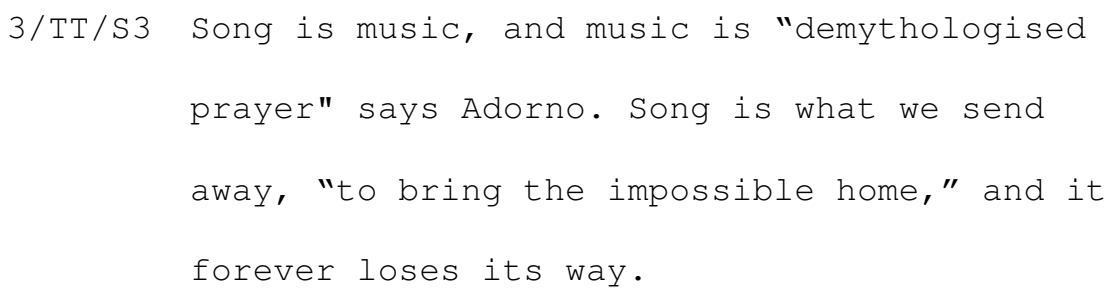

In datum 3, it illustrates that there is an efficiency in translating the noun phrase doa yang telah dilepaskan dari mithologi to demythologised prayer which can be classified as intrasystem shift as it doesnot involve unit or rank shift. Meanwhile, it involves the difference in the number of words employed of this expression in the source text and also target text. In the source text, doa yang telah dilepaskan dari mithologi is a noun phrase composed by relative clause while demythologised prayer comprises adjective. However, this strategy does not change the sense and meaning of the expression in the source text. In addition to the efficiency employed by the translator, tujuan which is translated to its way suggests that the translator aims to emphasize it by adding the possessive pronoun its.

The last stanza in the Poem No. 15 contains several similar expressions with those in the first stanza. Nonetheless, the interesting part of this stanza is that the translator utilizes different translation for junjunganku which can be seen in the following datum.

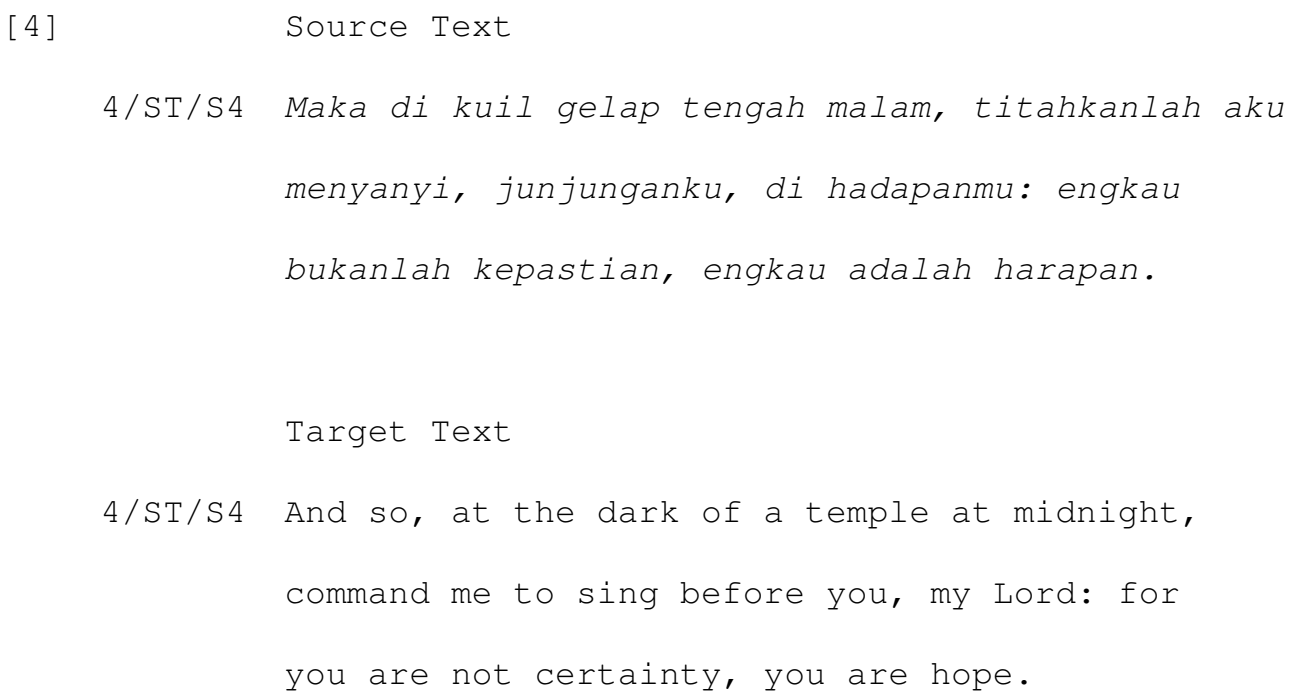

In datum 4, the translator uses my Lord to translate junjunganku instead of my master that she has used in the first stanza. This suggests that she reveals and addresses God by employing my Lord. This is in line with the theme and title of Goenawan Mohamad's poetry collection, On God and Other Unfinished Things in which this poem is included.

\section{CONCLUSION}

The various shifts found in the translation of Poem No. 15 in On God and Other Unfinished Thingsexpress the translator's effort also to make the target text more natural in English sense in providing a fluent aesthetic translation. The translation shifts occurring in the English translation of Poem No. 1533 in On God and Other Unfinished Things comprises class and intra-system shifts, and other expression shifts, such as the style and 
change or omission of certain parts in the poem. The various types of shifts in the translation of Poem No. 15 proves that the most essential aspect of translating the poem is the fluidity and the natural-ness of the translation or target text. Furthermore, the translator preserves the relevant aspects of the semantic content and the stylistic choices of the original poem to preserve the transparency of theme of Goenawan Mohamad's poem collection, On God and Other Unfinished Things.

The linguistic forms and stylistic features employed by the author in this poetic essay are both maintained and altered by the translator. Phonologically, several of those musical devices in the source text is not preserved in the target text as the translator decides to maintain the sense and meaning of the poem which also results in another kind of musical device exploited. Moreover, several examples of metaphor and also personification in Poem No. 15 are also translated in metaphors by the translator to ensure the fidelity of the metaphors and eases the readers to understand the ideas being explained in the poem.

In brief, there are several aspects both maintained and also modified by the translator in delivering the message of Goenawan Mohamad's Poem No. 15 in in On God and Other Unfinished Things, not only to preserve the aesthetic dimension of the language used in the poem but also to fulfill the expressive function of the text. The maintenance and alteration of certain expression in literary translation aim at providing target readers an aesthetically appropriate translation. By applying shift and preservingcertain components in the poem, the English translation of Poem No. 15 can fulfill its quality assessment required by its expressive text type. Thesestrategies strengthen the ideathat it is the crux of the matter for the translator to attain the standpoint or the perspective of the original author to fulfill and maintain the expressive function in his translation.

Analyzing a poem translation by using Reiss' method facilitates in assesing whether the language dimension used to transmit the message in the target text has already fulfilled the text function. As texts have an inherent type which differentiates it from other texts, be it informative, expressive, operative, or audio-medial, these distinctive text types will help the translator to specify the appropriate hierarchy of equivalence levels needed for a particular translation and to sharpen his awareness of linguistic markers of communicative function and functional translation units in providing an acceptable translation. However, there are still many grounds in this analysis by using Reiss' method that has not been explored. One of which is assesing audio-medial texts by using this method as this particular text type is considered new compared with the other three text types, informative, expressive, and operative. As this text type involves not only written words but also visual images and music, it makes audio-medial texts are challenging to be explored and will produce new and various findings that will broaden the field of translation studies and critical analysis.

\section{REFERENCES}

Baker, M.(2018).In Other Words: A Coursebook on Translation( $3^{\text {rd }}$ edn). New York: Routledge.

Boase-Beier, J., L. Fisher, \& H. Furukawa (2018).The Palgrave Handbook of Literary Translation. Cham: Palgrave Macmillan. 
Hatim, B.\& J. Munday.(2004). Translation: An Advanced Resource Book. New York: Routledge.

Landers, C. E.(2001).Literary Translation: A Practical Guide. Clevedon: Multilingual Matters.

Mohamad, G.(2007). On God and Other Unfinished Things. Translation by Laksmi Pamuntjak. Depok: KataKita.

Mohamad, G.(2007).Tuhan dan Hal-hal yang Tak Selesai. Depok: KataKita.

Munday, J.(2016).Introducing Translation Studies: Theories and Application( $4^{\text {th }}$ edn). New York: Routledge.

Newmark, P.(1988).A Textbook of Translation. Hertfordshire: Prentice Hall International.

Nord, C.(2018).Translating as a Purposeful Activity: Functionalist Approach Explained.(2 ${ }^{\text {nd }}$ edn). New York: Routledge.

Reiss, K.(2014).Translation Criticism: The Potentials and Limitations. Translation by Erroll F. Rhodes. New York: Routledge.

Reiss, K.\& H. J. Vermeer.(2014).Towards a General Theory of Translational Action: Skopos Theory Explained. Translation by Christiane Nord. New York: Routledge.

Williams, J.\& A. Chesterman.(2002).The Map: A Beginner's Guide to Doing Research in Translation Studies. Manchester: St. Jerome Publishing. 


\section{APPENDIX}

1. Source Text Taken from Goenawan Mohamad's Poem No. 15 in Tuhan dan Hal-hal yang Tak Selesai

.... di kuil gelap tengah malam, titahkanlah aku berdiri di

hadapanmu, junjunganku, untuk menyanyi -- Tagore

Titahkan aku menyanyi, karena nyanyi tak

menatapmu, tak membacamu. Tak ada berhala,

tak ada negosiasi dengan makna. Nyanyi

adalah suara dalam jurang, di mana kedekatan

membutakan kata-kata. Nyanyi tak memanggul

seluruh niat, juga niatnya sendiri, karena ia

sebenarnya hanya mencoba.

Nyanyi adalah musik, dan musik adalah "doa yang

telah dilepaskan dari mithologi," kata Adorno.

Nyanyi adalah yang kita kirim pergi, "agar

membawa pulang sesuatu yang mustahil." dan ia

selamanya kehilangan tujuan.

Maka di kuil gelap tengah malam, titahkanlah aku

menyanyi, junjunganku, di hadapanmu: engkau

bukanlah kepastian, engkau adalah harapan.

Mohamad, G.(2007). Tuhan dan Hal-hal yang Tak Selesai. Depok: KataKita. 


\section{Target Text Taken from Goenawan Mohamad's Poem No. 15 in On God and Other Unfinished Things}

“... at the dark temple of midnight, command

me, my master, to stand before thee to sing."

\section{Tagore}

Command me to sing, because song does not gaze at you, does not read you. There are no idols, no negatiations with meaning. Song is the sound of abyss, where proximity blinds words. Song does not shoulder each intention, least of all its own, because it merely tries.

Song is music, and music is "demythologised prayer," says Adorno. Song is what we send away, "to bring the impossible home," and it forever loses its way.

And so, at the dark of a temple at midnight, command me to sing before you, my Lord: for you are not certainty, you are hope.

Mohamad, G.(2007). On God and Other Unfinished Things. Translation by Laksmi Pamuntjak. Depok: KataKita. 


\section{Table of Source Text and Target Text of Goenawan Mohamad's Poem No. 15 in On God and Other Unfinished Things}

\begin{tabular}{|c|c|c|c|}
\hline $\begin{array}{c}\text { ST Data } \\
\text { Code }\end{array}$ & Source Text & $\begin{array}{c}\text { TT Data } \\
\text { Code }\end{array}$ & Target Text \\
\hline 1/ST/S1 & $\begin{array}{l}\text {... di kuil gelap tengah malam, } \\
\text { titahkanlah aku berdiri di } \\
\text { hadapanmu, junjunganku, untuk } \\
\text { menyanyi -- Tagore }\end{array}$ & 1/TT/S1 & $\begin{array}{l}\text { "... at the dark temple of } \\
\text { midnight, command } \\
\text { me, my master, to stand before } \\
\text { thee to sing." } \\
\text { Tagore }\end{array}$ \\
\hline 2/ST/S2 & $\begin{array}{l}\text { Titahkan aku menyanyi, karena } \\
\text { nyanyi tak } \\
\text { menatapmu, tak membacamu. Tak } \\
\text { ada berhala, } \\
\text { tak ada negosiasi dengan makna. } \\
\text { Nyanyi } \\
\text { adalah suara dalam jurang, di mana } \\
\text { kedekatan } \\
\text { membutakan kata-kata. Nyanyi tak } \\
\text { memanggul } \\
\text { seluruh niat, juga niatnya sendiri, } \\
\text { karena ia } \\
\text { sebenarnya hanya mencoba. }\end{array}$ & 2/TT/S2 & $\begin{array}{l}\text { Command me to sing, because } \\
\text { song does not } \\
\text { gaze at you, does not read you. } \\
\text { There are no } \\
\text { idols, no negatiations with } \\
\text { meaning. Song is the } \\
\text { sound of abyss, where proximity } \\
\text { blinds words. } \\
\text { Song does not shoulder each } \\
\text { intention, least of } \\
\text { all its own, because it merely tries. }\end{array}$ \\
\hline 3/ST/S3 & $\begin{array}{l}\text { Nyanyi adalah musik, dan musik } \\
\text { adalah "doa yang } \\
\text { telah dilepaskan dari mithologi," } \\
\text { kata Adorno. } \\
\text { Nyanyi adalah yang kita kirim } \\
\text { pergi, "agar } \\
\text { membawa pulang sesuatu yang } \\
\text { mustahil." dan ia } \\
\text { selamanya kehilangan tujuan. }\end{array}$ & 3/TT/S3 & $\begin{array}{l}\text { Song is music, and music is } \\
\text { "demythologised } \\
\text { prayer," says Adorno. Song is } \\
\text { what we send } \\
\text { away, "to bring the impossible } \\
\text { home," and it } \\
\text { forever loses its way. }\end{array}$ \\
\hline 4/ST/S4 & $\begin{array}{l}\text { Maka di kuil gelap tengah malam, } \\
\text { titahkanlah aku } \\
\text { menyanyi, junjunganku, di }\end{array}$ & 4/TT/S4 & $\begin{array}{l}\text { And so, at the dark of a temple at } \\
\text { midnight, } \\
\text { command me to sing before you, }\end{array}$ \\
\hline
\end{tabular}




\begin{tabular}{|l|l|l|l|}
\hline & $\begin{array}{l}\text { hadapanmu: engkau } \\
\text { bukanlah kepastian, engkau adalah } \\
\text { harapan. }\end{array}$ & $\begin{array}{l}\text { my Lord: for } \\
\text { hope. }\end{array}$ \\
\hline
\end{tabular}

